\title{
METODE EKSPERIMEN MEDIA AIR UNTUK PERKEMBANGAN SOSIAL ANAK USIA DINI
}

\author{
Anisa Yunita Sari ${ }^{1}$, Andini Dwi Arumsari ${ }^{2}$ \\ Universitas Narotama ${ }^{1,2}$ \\ Email: anisa.yunita@narotama.ac.id, andini.dwi@narotama.ac.id
}

\begin{abstract}
ABSTRAK
Pembelajaran menggunakan metode eksperimen tidak hanya memberikan kontribusi pada perkembngan kognitif tetapi juga memberikan kontribusi pada perkembanagan sosial anak usia dini. Melalui metode eksperimen anak diberi kesempatan untuk mengalami sendiri, mengikuti suatu proses, mengamati suatu obyek dan keadaan. Anak akan belajar untuk memiliki karakter tidak mudah menyerah untuk melakukan suatu percobaan, ada beberapa bentuk metode eksperimen dalam implementasinya dilakukan berkelompok sehingga akan melatih sikap toleransi saat anak mengantri untuk mengambil alat-alat yang akan digunakan dalam eksperimen, tidak menggangu teman yang sedang melakukan kegiatan dan dapat melatih mencerminkan sikap yang bersifat peduli misalkan bersedia bermain dengan teman sebaya, dan memiliki sikap tanggung jawab untuk merapikan dan merawat alat yang digunakan dalam eksperimen. Jadi dapat disimpulkan bahwa dengan menggunakan metode eksperimen dapat melatih perkembangan sosial anak usia dini.
\end{abstract}

Kata kunci: metode eksperimen, perkembangan sosial, anak usia dini

\begin{abstract}
Abstrasct
Learning by using experimental methods not only contributes to cognitive development but also contributes to early childhood social development. Through the experimental method, the child is given the opportunity to experience by himself, pursue a process, observe an object and situations. Children will learn to have characters not to give up easily to do an experiment, there are several forms of experimental methods in the implementation carried out in groups so that they will practice tolerance when children queue to take the tools that will be used in the experiment, not interfere with friends who are doing activities and can train reflecting caring attitudes, for example willing to play with peers, and have an attitude of responsibility to tidy up and care for the tools used in the experiment. So it can be concluded that using the experimental method can train early childhood social development.
\end{abstract}

Keywords: experimental methods, social development, early childhood

\section{PENDAHULUAN}

Pendidikan TK merupakan jembatan pendidikan dari lingkungan keluarga dengan masyarakat yang lebih luas dan memiliki tugas yang penting dalam memberikan stimulasi untuk mengembangkan berbagai potensi anak terkait aspek sosial emosional, bahasa dan estetika (Kemendiknas, 2010:1).

Fernie (dalam Solehuddin, 1997:6) meyakini bahwa pengalaman-pengalaman belajar awal tidak akan pernah bisa diganti 
oleh pengalaman-pengalaman belajar berikutnya, kecuali dimodifikasi. Hal tersebut juga sejalan dengan pendapat Bloom (dalam Sudarna, 2014:20) yang menyatakan bahwa pendidikan pada anak usia dini akan memberikan dampak pada pertumbuhan anak pada fase selanjutnya.

Menurut Aqid (2009:9)

Taman Kanak-Kanak (TK) sebagai salah satu bentuk satuan pendidikan anak usia dini (PAUD) yang bertujuan untuk membantu meletakkan dasar kearah perkembangan sikap, pengetahuan, keterampilan, dan daya cipta yang diperlukan oleh anak dalam menyesuaikan diri dengan lingkunganya dan perkembangan selanjutnya. Oleh karena itu pendidikan anak usia dini di TK perlu diciptakan situasi pendidikan yang memberikan rasa aman dan menyenangkan.

Pestalozzi (dalam Masitoh, 2007:18) mengatakan bahwa pendidikan TK hendaknya menyediakan pengalamanpengalaman yang menyenangkan, bermakna, dan hangat seperti yang diberikan oleh orang tua di lingkungan rumah. Kondisi yang menyenangkan dan aman akan mengaktifkan bagian neocortex (otak berpikir) dan mengoptimalisasikan kegiatan belajar pada anak.Anak usia dini memiliki karakteristik aktif untuk mengetahui segala hal karena berkaitan dengan perkembangan intelektual anak yang berkembang sangat pesat dan berada pada masa peka. Masa ini hanya terjadi sekali pada rentan hidup manusia.

Kecenderungan anak untuk berfikir kritis ini harus disalurkan melalui kegiatan-kegiatan yang bermakana dalam artian dapat dimengerti dan berguna bagi keberlangsungan hidup anak.Salah satu kegiatan yang bermakna dan dapat dilakukan untuk menstimulus perkembangan anak sesuai dengan karakteristiknya adalah, dengan memberikan kegiatan yang memungkinkan anak untuk dapat melakukan eksplorasi dan juga eksperimen serta melakukan pengamatan kejadian-kejadian disekitarnya.

Dewey (1897:4) dengan teorinya "learning by doing" menyatakan bahwa anak-anak akan belajar dengan melakukan, sehingga anak dapat menerima pengalaman baru secara langsung. Pengalaman anak harus berada pada kondisi internal, karena naluri dan kekuatan anak memberikan materi dan memberikan titik awal untuk semua pendidikan. Berdasarkan dari teori yang tersebut maka dapat disimpulkan bahwa pembelajaran harus berpusat pada anak.

Vygotsky (dalam Sudjiono, 2009:115) percaya bahwa kemampuan kognitif akan berkembang pada anak yaitu saat terjadinya interaksi anak dengan lingkungan sosialnya, dalam artian dengan berinteraksi dengan lingkungan sosial, anak-anak mendapatkan informasi baik dari teman sebaya maupun dengan orang 
dewasa sehingga menimbulkan percepatan pemahaman anak-anak. Pendapat tersebut juga senada dengan Piaget (dalam Catron dan Allen, 1997:7) percaya bahwa anakanak itu membangun pengetahuanya melalui interaksi dengan lingkunganya.

\section{KAJIAN TEORI}

\section{Metode Eksperimen Media Air}

Metode pembelajaran merupakan cara yang dilakukan oleh guru untuk membelajarkan anak dalam mencapai kompetensi yang telah ditetapkan (Depdiknas, 2004:11). Muslichatoen (2004:7) menyatakan bahwa metode merupakan bagian dari kegiatan. Metode merupakan langkah awal yang digunakan untuk mencapai tujuan dalam pembelajaran yang diterapkan oleh pendidik.

Metode eksperimen atau dikenal juga dengan istilah “experimental learning”mulai diperkenalkan pada tahun 1984 oleh David Kolb dalam bukunya yang berjudul "Experimental learning, experience as a the source of learning and development". Metode eksperimen didefinisikan sebagai pengetahuan yang diciptakan melalui bentuk perubahan pengalaman. "Learning is the process where by knowledge is created throught the transformation of experience" (Kolb: 1984:38)

Metode Eksperimen menurut Rostiyah (2001:80) adalah suatu kegiatan yang di dalamnya dilakukan percobaan dengan cara mengamati proses dan hasil dari percobaan tersebut. Metode eksperimen menurut Djamarah (2002: 42) adalah cara penyajian pembelajaran, dimana anak melakukan percobaan dengan mengalami sendiri sesuatu yang dipelajari.

Patrick (2011) mengatakan bahwa metode eksperimen adalah "Experimental learning is the process of learning throught experience and is more specifically defined as learning throught reflection on doing". Clark (2011) menerangkan bahwa metode eksperimen adalah "Experience means relating to or resulting from experience while experimental means relating or based on experiment"

Dari penjabaran di atas maka dapat diambil kesimpulan bahwa metode eksperimen adalah suatu aktivitas yang berkaitan dengan melakukan percobaan yang diperoleh dari hasil pengalaman langsung oleh anak untuk mengamati suatu proses dan hasil dari percobaan tersebut .

Melalui metode eksperimen anak diberi kesempatan untuk mengalami sendiri, mengikuti suatu proses, mengamati suatu obyek dan keadaan. Dengan demikian, anak dapat mencari kebenaran, atau mencoba mencari suatu hukum atau dalil, dan menarik kesimpulan dari proses yang dialaminya itu melalui percobaan yang dilakukan.Metode eksperimen merupakan cara pembelajaran yang berpusat kepada anak. Pembelajaran dengan menggunakan metode eksperimen 
tidak hanya membuat anak sebatas mengetahui dan hafal tetapi anak memahami.

Aspek perkembangan sosial yang ada pada metode eksperimen yang dilakukan adalah: mencerminkan sikap yang bersifat sabar misalkan pada saat anak mengantri untuk mengambil alat-alat yang akan digunakan dalam eksperimen, tidak menggangu teman yang sedang melakukan kegiatan mencerminkan sikap yang bersifat peduli misalkan bersedia bermain dengan teman sebaya, bersedia bekerjasama dengan teman sebaya, dan berbagi dngan teman sebaya.

Sumber utama bentuk pembelajaran barang sesungguhnya ini adalah sumber daya alam yang berada dilingkungan sekitar anak. Bahan-bahan pembelajaran yang berada disekitar anak akan mudah untuk diingat, dilihat dan dipraktikkan sehingga kegiatan pembelajaran juga berfungsi secara praktis. Melalui bentuk pembelajaran ini akan tumbuh keaktifan anak untuk mengamati, menyelidiki serta mempelajari lingkungan.

Interaksi sosial anak terhadap lingkunganya sangat menunjang dan memberikan kontribusi yang berarti dalam perkembangan anak. Perkembangan anak terjadi secara holistik, pada saat anak berada di lingkungan sosial maka secara tidak langsung anak juga mendapatkan pengalaman lain dari lingkungan tersebut, misalkan berbahasa, kognitif, moral agama dan bahkan juga motorik.
Jika anak tidak mengalami hambatan dalam lingkungan sosialnya maka akan terjadi percepatan dalam perkembangan anak, begitu juga sebaliknya. Agar anak dapat masuk dalam lingkungan sosial maka diperlukan kemampuan dalam bersosialisasi.

Jadi dapat disimpulkan bahwa agar anak-anak mendapatkan manfaat dari interaksi sosial maka anak harus memiliki perkembangan sosial yang baik dan dapat diterima menjadi bagian dari anggota kelompok sosial. Untuk menjadi bagian dari kelompok itu maka anak harus mengikuti tata krama yang berlaku.

Metode eksperimen yang dilakukan adalah dengan eksperimen menggunakan bahan dasar air. Montesori (dalam Sudono, 2006:03) menyatakan bahwa sebenarnya lingkungan atau alam sekitar yang mengundang anak untuk menyenangi pembelajaran, dan air merupakan bagian dari lingkungan/alam tersebut. Pendapat lain juga dikemukakan oleh (Eschach \& Fried, 2005; Ramey-Gassert, 1997) children have a natural tendency to enjoy observing and thinking about nature".

Air memiliki karakter yang berbeda dengan aspek lingkungan alam lain, keunggulan dari sifat air adalah bisa dilihat dan bisa dirasakan tetapi tidak bisa dipegang. Dengan karakteristik air yang tidak bisa dipegang membuat anak semakin penasaran serta gemar untuk bereksplorasi dan bereksperimen 
dengan air, selain itu air juga memiliki sensasi rasa dingin dan basah yang digemari oleh anakanak.

Keberadaan air sangat mudah untuk dijumpai oleh anak karena setiap hari anak akan bersentuhan dengan air misalkan untuk mandi, minum, mencuci tangan dsb. Bahan-bahan pembelajaran yang berada disekitar anak akan mudah untuk diingat, dipraktikkan sehingga pembelajaran dapat berfungsi secara praktis (Brewer:2007). Melalui bentuk pembelajaran yang berfungsi secara praktis maka akan menumbuhkan keaktifan anak untuk mengamati, menyelidiki serta mempelajari lingkungan.

Aspek perkembangan sosial yang ada pada metode eksperimen yang dilakukan adalah: mencerminkan perilaku yang bersifat sabar misalkan pada saat anak mengantri untuk mengambil alat-alat yang akan digunakan dalam eksperimen, mencerminkan sifat peduli pada saat anak menjaga barang milik sendiri maupun barang milik orang lain, memiliki sikap percaya diri pada saat anak meceritakan hasil eksperimen yang telah dilakukan, mencerminkan sikap tanggung jawab pada saat anak membersihkan alat yang digunakan dalam eksperimen yang telah dilakukan.

\section{Perkembangan Sosial}

Perkembangna sosial anak adalah kepekaan anak memahami perasaan orang lain ketika berinteraksi dalam kehidupan seharihari (Suyadi dan Ulfa, 2010:119). Perkembangan sosial anak dimulai dari sikap egoisentris yang hanya memandang dari satu sisi dirinya sendiri. Anak tidak mengerti bahwa orang lain dapat berpandangan berbeda dengan dirinya. Adanya sifat egoisentris yang tinggi ini menunjukkan bahwa anak belum dapat memahami perbedaan pendapat orang lain.

Pendapat lain dikemukakan oleh Sutirna (2014:118) yang menyatakan bahwa perkembangan sosial adalah proses perolehan kemampuan untuk berperilaku yang sesuai dengan keinginan yang berasal dari dalam diri seseorang dan sesuai dengan tuntutan dan harapanharapan sosial yang berlaku dalam masyarakat. Hal tersebut juga selaras dengan Hurlock (1993) yang menyatakan bahwa perkembangan sosial merupakan perolehan kemampuan berperilaku yang sesuai dengan tuntutan sosial.

Jadi dapat disimpulkan bahwa definisi perkembangan sosial berdasarkan pendapat ahli yang telah dijabarkan diatas maka diperoleh pengertian bahwa perkembangan sosial merupakan suatu proses pembembentukan sosial self (pribadi dalam masyarakat), yakni pribadi dalam keluarga, budaya, bangsa dan seterusnya.

Perkembangan sosial erat kaitanya dengan kemampuan mandiri, bersosialisasi dan berinteraksi dengan lingkunganya. Sosialisasi merupakan suatu proses 
interaksi diantara anak yang sedang berkembangan dengan orang lain. Sosialisasi meliputi pengetahuan, kecakapan dan teknik-teknik yang melakukan sesuatu penyesuaian adaptif diantara anak-anak dengan lingkungan tempat tinggal anak (Soetjiningsih, 2002:65-71).

Jadi dapat disimpulkan bahwa makna sosial dipahami sebagai upaya pengenalan anak terhadap orang lain yang berada di luar dirinya maupun diluar lingkunganya, serta pengaruh timbal balik dari segi kehidupan bersama (interaksi), baik dalam bentuk perorangan maupun dalam bentuk kelompok.

Perkembangan sosial berkaitan dengan kemampuan berperilaku yang sesuai dengan tuntutan sosial. Pola perilaku dibina pada masa anak-anak awal (2-6 tahun) atau masa pembentukan. Pada masa 4-6 tahun sudah terdapat hubungan sosial untuk bergaul dengan orang-orang di luar rumah, terutama dengan anak-anak seumuran. Anak belajar untuk beradaptasi dan mulai mengenal istilah kerjasama dalam kegiatan bermain. Pada masa ini anak mengalami perubahan yang sangat cepat dan mulai mengadakan interaksi dinamis dengan lingkungan sekitar.

Anak usia TK memiliki dorongan yang kuat untuk mendapatkan pengakuan dari kelompok anak sebaya. Jika terjadi hambatan yang menyebabkan anak tersebut tidak dapat diterima oleh lingkungan sekitar, maka anak akan berusaha untuk mencari cara agar dapat diterima oleh lingkungan sosial. Keinginan anak untuk diakui, maka akan menuntut sejumlah kemampuan sosial yang dimiliki.

Permasalahan yang timbul adalah tidak semua anak dapat menunjukkan sikap sosial seperti yang diharapkan dan tidak semua anak mampu berinteraksi dengan kelompok teman sebaya secara baik. Bimbingan sosial diperlukan anak untuk dapat bersosialisasi dengan baik di lingkungan sekitar, sehingga anak merasa nyaman karena bisa beradaptasi, dan sebaliknya lingkungan juga dapat menerima.

Froebel (dalam Sollehuddin, 1997:27) seorang ahli pendidikan Swiis menyatakan bahwa pada dasarnya anak berpembawaan baik (innate goodness) dan berpotensi kreatif (creative potencial). Montesori (dalam Solehuddin, 1997: 27) menyatakan bahwa di dalam jiwa anak terdapat jiwa menyerap (obserbent mind) yaitu gejala psikis yang memungkinkan anak membangun pengetahuan dengan cara menyerap sesuatu dari lingkunganya dan menggabungkan pengetahuan yang diperoleh secara langsung dalam kehidupan psikisnya. Jadi dapat diambil kesimpulan bahwa secara bawaan, kecenderungan perkembangan anak mengarah kepada sesuatu yang baik, tidak ada anak dengan predikat "nakal" semua anak adalah "baik". Baik ataupun buruk perlakuan anak terletak pada perlakuan lingkungan, 
apakah lingkungan memberikan kesempatan kepada anak untuk mengembangkan potensi-potensinya dan memberikan teladan yang baik bagi anak.

Menurut Froebel (dalam Roopnaire, JL \&Johnson, JE, 1993:56) masa anak-anak merupakan fase yang sangat penting, berharga dan masa pembentukan dalam periode kehidupan manusia (a noble and maleable phase of human life). Hal ini juga selaras dengan pendapat Montesori (dalam Hainstock, 1999:10-11) mengatakan bahwa masa anak-anak merupakan periode sensitif, selama masa inilah anakanak mudah untuk menerima stimulus-stimulus dari lingkungan.

Jadi dapat disimpulkan bahwa pendidikan anak pada usia dini sangat penting terutama pendidikan yang mengarah pada pendidikan sosial yang memiliki korelasi dengan pendidikan karakter, karena berkaitan dengan kemampuan anak untuk berinteraksi dengan sosial, sebagaimana manusia adalah makhluk sosial.

Untuk mengembangkan sikap sosial maka perlu ditanamkan sejak dini melalui pengalamanpemgalaman interaksional pendidikan. Kondisi yang diperlukan untuk perkembangan ini adalah: adanya interaksi yang terpadu antara anak dengan lingkungan, dan adanya kebebasan bagi anak.

\section{Karakteristik Perkembangan Sosial Anak}

Berdasarkan pendapat Erickson (dalam Dodge dan Colker, 2000:5-10) dan sejalan dengan pendapat Dworettzky (1996:339) berpendapat bahwa perkembangan sosio-emosional yang penting untuk dikembangkan dan harus dipelajari pada anak-anak adalah rasa percaya terhadap lingkungan luar diri anak (to trust other outside their families), kemandirian dan pengendalian diri (to gain independence and self control) dan inisiatif serta belajar berperilaku agar dapat diterima oleh kelompok (to take initiative and assert themselves in sosial acceptable ways) .

Erikson (dalam Morrison, 2012:82) dengan teorinya psikososial berpendapat bahwa perkembangan sosial dan kognitif terjadi bersama dan tidak dapat dipisahkan, kepribadian dan keterampilan sosial anak tumbuh dan berkembang di dalam masyarakat dan institusi sosial seperti keluarga, sekolah, dan program pendidikan anak. Orang dewasa terutama orang tua merupakan agen perubahan yang memiliki andil paling besar dalam hal membantu atau menghalangi perkembangn sosial anak. Oleh karena itu orang tua atau pendidik harus mengetahui tahap-tahap perkembangan yang terjadi pada anak agar dapat memberikan stimulus yang tepat.

Selain perkembangan kognitif yang semakin matang anak juga lebih banyak bermain, dan bercakap-cakap dengan anak lainya. Menurut Parten dan Rogers (dalam 
Docket dan Fleer, 2000:62) pada tahapan usia 5-6 tahun anak memasuki tahapan bermain assosiatif play atau bermain dengan teman dan juga memasuki tahapan bermain cooperative or organized supplementary atau kerjasama dalam bermain atau dengan aturan. Dari tahapan bermain yang ada pada anak tersebut maka dapat dipastikan bahwa dengan bermain, anak mengembangkan kemampuanya dalam belajar untuk bersosialisasi dan berinteraksi dengan orang lain.

Dengan adanya intensitas interaksi terpadu antara anak dengan lingkunganya semakin meningkat baik di lingkungan sekolah maupun di lingkungan rumah. Dengan adanya interaksi anak dengan sosial maka anak akan memahami dirinya sendiri untuk bersikap kooperatif, toleran, menyesuaikan diri dan mentaati aturan yang berlaku. Anak juga mulai mematuhi tata krama yang berlaku agar lebih diterima dengan lingkungan sosialnya.

Tata krama ini merupakan cara dalam kehidupan sosial atau cara-cara yang dianggap baik dalam pergaulan antar manusia (Sidharto dan Rita, 2007:3). Tata krama dapat bersumber dari falsafah hidup suatu masyarakat atau bangsa, bisa juga berasal dari ajaran agama yang diyakini. Dalam perspektif islam hubungan sosial dengan sesama manusia disebut dengan istilah habluminannas (Wiyani, 2014:35). Jadi dapat disimpulkan bahwa dalam kehidupan sosial bermasyarakat agar anak dapat diterima maka harus mematuhi tata krama yang berlaku. Setiap lingkungan masyarakat memiliki aturan yang berbeda-beda dan anak diharapkan dapat mengetahui aturan tersebut yang biasanya berkaitaan dengan adat istiadat dan tata krama yang berlaku di lingkungan tempat anak tinggal.

\section{Urgensi Perkembangan Perilaku Sosial \\ Vygotsky (dalam Solehudin,} 2004:1) memandang bahwa kognisi itu merupakan suatu fenomena sosial atau sesuatu yang dibangun secara sosial. Pengalaman sosial membentuk cara berfikir dan cara mengintepretasikan lingkungan. Hal tersebut juga berkaitan dengan teori Vygotsky (dalam Sujiono, 2009: 115) mengenai scaffolding dan ZPD.

Berfikir tidak hanya dibatasi oleh otak individu semata tetapi juga dipengaruhi oleh pemikiranpemikiran orang lain. Jadi dapat disimpulkan bahwa pengetahuan dibangun oleh anak berdasarkan dengan kemampuan dalam memahami perbedaan berdasarkan persamaan yang tampak, peranan lingkungan sosial sangat membantu anak untuk mengalami percepatan dalam pembelajaran.

Vygotsky (dalam Berk, L.E \& Winsler, A., 1995) berpendapat bahwa konteks sosial memiliki pengaruh untuk proses belajar anak, dan pengalaman interaksi sosial ini sangat berperan dalam pengembangan kemampuan berpikir anak, serta aktivitas mental yang tertinggi diperoleh dari konteks 
sosial dan budaya tempat anak berinteraksi dengan teman-teman sebaya ataupun dengan orang lain. Oleh karena itu untuk memahami perkembangan anak, maka harus memahami relasi-relasi sosial yang terjadi di tempat anak bergaul.

Piaget (dalam Catron dan Allen, 1997:7-8) percaya bahwa anak-anak itu membangun pengetahuan melalui interaksi dengan lingkungan. Anak-anak bukanlah suatu objek penerima pengetahuan yang pasif, melainkan anak dengan aktif melakukan pengaturan pengalaman anak ke dalam struktur mental yang lebih kompleks.

Jadi dapat disimpulkan bahwa peranan lingkungan sosial memberikan kontribusi yang sangat bermanfaat bagi perkembangan anak. Perkembangan anak terjadi secara holistik, pada saat anak berada di lingkungan sosial maka secara tidak langsung anak juga mendapatkan pengalaman lain dari lingkungan tersebut, misalkan berbahasa, kognitif, moral agama dan bahkan juga motorik. Pengalaman yang berkaitan dengan motorik ini sifatnya insidental jika anak melakukan aktifitas gerak dalam bersosialisasi. Jadi dapat disimpulkan jika anak tidak mengalami hambatan dalam lingkungan sosial maka akan terjadi percepatan dalam perkembangan anak, begitu juga sebaliknya. Agar anak dapat masuk dalam lingkungan sosial maka diperlukan keterampilan dalam bersosialisasi.
Perkembangan sosial berkaitan dengan kemampuan untuk menilai apa yang sedang terjadi dalam suatu situasi sosial, keterampilan untuk merasa dan dengan tepat mengintepretasikan tindakan dan kebutuhan dari anakanak di kelompok bermain, dan kemampuan untuk membayangkan bermacam-macam tindakan yang memungkinkan. Anak-anak yang berhasil secara sosial sering menunjukkan kemampuan untuk bersosialisasi dengan baik, sedangkan anak-anak yang memiliki keterampilan sosial yang rendah memerlukan instruksi secara langsung untuk modeling (Sujiono, 2009:73). Dari penjabaran tersebut maka dapat disimpulkan jika peranan orang dewasa sangat diperlukan sebagai fasilitator agar anak memiliki keterampilan sosial yang diharapkan dan dapat memasuki lingkup sosial yang terbentuk disekitar anak.

\section{SIMPULAN}

Berdasarkan penjabaran
diatas maka dapat disimpulkan
bahwa dengan menggunakan metode
eksperimen media air maka dapat
memberikan stimulus pada perkembanagnm sosial anak. Contoh perkembangan sosial yang dapat diasah melalui metode eksperimen adalah: mencerminkan sikap yang bersifat sabar misalkan pada saat anak mengantri untuk mengambil alat-alat yang akan digunakan dalam eksperimen, tidak menggangu teman 
yang sedang melakukan kegiatan mencerminkan sikap yang bersifat peduli misalkan bersedia bermain dengan teman sebaya, bersedia bekerjasama dengan teman sebaya, dan berbagi dengan teman sebaya memiliki rasa tanggung jawab untuk merapikan kembali alat yang sudah digunakan dan melatih untuk memiliki rasa menjaga dan merawat yang digunakan dalam eksperimen.

Kemampuan kognitif akan berkembang pada anak yaitu saat terjadinya interaksi anak dengan lingkungan sosialnya, dalam artian dengan berinteraksi dengan lingkungan sosial, anak-anak mendapatkan informasi baik dari teman sebaya maupun dengan orang dewasa sehingga menimbulkan percepatan pemahaman anak-anak

\section{DAFTAR PUSTAKA}

Aqid, Z, dkk. 2009. Penelitian Tindakan Kelas Untuk Guru. Bandung: Yrama Widya

Berk L. E dan A. Winsler. 1995. Scaffolding Children Learning:Vygotsky And Early Childhood Education. Washington DC: NAECY

Bryce. Seefeld, Carol. 2001. Technology Young Children. New Jersey: Prentice Hall Inc

Catron, Carol. Edan Jan Allen. 1999. Early Childhood Curriculu: A Creative Play Model, $2^{\text {nd }}$ edition. New Jersey:Merill Publ

Clark Donald. 2011. Kolb S Leraning Style And Experintal Learningmodel. (www.nwlink.com/donclark /hrd/style/kolb.html), Diakses pada 13 November 2011

Dewey, J. 1897. My Pedagogic Creed, In Dewey, J (1940) Education Today, New York:Greenwood Press

Djamarah, Syaiful Basri. 2002. Psikologi Belajar. Jakarta:Rhineka Cipta

Docket, Sue dan Marlyn Fleer. 2000. Play And Pedagogy In Early Childhood-Bending The Rules Sidney:Hartcourt

Dodge, Diane Trisler And Laura J. Colker. 2000. Creatives Curriculum For Early 
Childhood. Washington,

DC: Teaching Strategy.

Dworetzky, John P. Tanpa Tahun.

Introduction To Child

Development. Saint Paul,

Minnepolis: West

Publishing Company.

Eshach \& Fried M.N. 2005. Should

Science Be Tought In Early

Childhood? Journal of

Science Education And

Technology, 14 (3), 315-336

Hainstock, Elizabeth G. 1999.

Metode Pengajaran

Montesori Untuk Anak

Prasekolah.Jakarta: Pustaka

Dalaprasa .

Hurlock, Elizabeth, B. 1978. Child

Development, Sixt Edition.

New York; Mc Graw Hill, Inc

Hurlock, Elizabeth. 1993.

Perkembangan Anak.

Jakarta. Erlangga

Kemendiknas. 2010. Kumpulan

Pedoman Pembelajaran

Taman Kanak-Kanak.

Jakarta: Kemendiknas RI

Masitoh, Et. Al. 2007. Pendekatan

Belajar Aktif Di Taman

Kanak-Kanak.

Jakarta:Departemen

Pendidikan Nasional

Moeslichatoen. 2004. Metode

Pengajaran Di Taman

Kanak-Kanak. Jakarta:PT

Rhineka Cipta

Morrison, George S. 2012. Dasar-

Dasar Pendidikan Anak

Usia Dini (PAUD). Jakarta:

PT Indeks
Patrick, Falicia. 2011. Handbook Of Research On Improfiny Learning And Motivation.

Ramey-Gassert, L. 1997. Learning Science Beyond The Classroom. The Elementary School Journal, 97(4), 433450.

Roopnaire, J.L\& Johnson, J.E. 1993. Approaches to early Childhood, Education, $2^{\text {nd }}$ Edition, New York: Meril

Rostiyah N.K. 2001.Strategi Belajar Mengajar. Jakarta: Rineka Cipta

Solehudin, M. 1997. Konsep Dasar Pendidikan Prasekolah. Bandung: FIP UPI

Sudarna. 2012. Pendidikan Anak Usia Dini. Yogyakarta:Rosda

Sudono, Anggarani. 2006. Sumber Belajar Dan Alat Permainan. Jakarta: PT Gramedia

Sujiono, Yuliani Nurani. 2009. Konsep Dasar Pendidikan Anak Usia Dini. Jakarta: PT Indeks

Sidharto, Suryati dan Rita Ekka Izzaty. 2007.

Pengembangan Kebiasaan Positif: Social Life Skill Untuk Anak Usia Dini. Yogyakarta: Tiara Wacana.

Sutirna. 2013. Perkembangan dan Pertumbuhan Peserta Didik. Yogyakarta: Andi Offset

Suyadi. 2014. Konsep Dasar Anak

Usia Dini Neorosience. Yogyakarta:Rosda

Suyadi dan Maulidya Ulfa. 2010. Konsep Dasar Paud. 
Bandung: $\quad$ Remaja
Rosdakarya

Wiyani Novan Andri. 2014.

Mengelola Dan

Mengembangkan

Kecerdasan Sosial Emosi

Anak Usia Dini.

Yogyakarta: Ar Rus Media

Yulianti, Dwi. 2010. Bermain Sambil

Belajar Sains di Taman

Kanak-Kanak. Jakarta: PT

Indeks 